\title{
PEER PRESSURE AND THE USE OF DRUGS AMONG UNIVERSITY STUDENTS \\ Mirjana Radetić-Paić
}

Faculty of Educational Sciences, Juraj Dobrila University of Pula, Croatia.

Email: mirjana.radetic-paic@unipu.hr

Article History: Received on $30^{\text {th }}$ March 2020, Revised on $24^{\text {th }}$ May 2020, Published on $22^{\text {nd }}$ June 2020

\begin{abstract}
Purpose: The purpose of this study is to identify the correlation between certain peer pressure characteristics and drug consumption in adolescents. Peer relationships have a key role in the adolescent period. In a negative context, peer pressure can be done in various ways that benefit from the characteristics of growing adolescents, who are often insecure and need a sense of acceptance and belonging.
\end{abstract}

Methodology: This study adopted a survey method and data was collected from 234 students from the Juraj Dobrila University of Pula, Croatia, on peer pressure questionnaires. For analysing the data SPSS was used.

Main Findings: The findings of this study verify the existence of a statistically significant correlation between certain peer pressure characteristics and drug consumption aiming at experiencing the feeling which the rest of the peer group already has.

Implications/ Applications: The value of the results, besides obtaining valuable new indicators based on scientific research methods, is that they offer guidelines for prevention and intervention in cases of various peer problems and problems with the abuse of addictive substances.

The novelty of the Study: Drug consumption has become one of the prevailing problems in adults in the current era. This study is enhancing the literature by investigating the role that peer pressure plays in drug consumption.

Keywords: Drug Abuse, Peers, Influence, Pressures, University Students.

\section{INTRODUCTION}

Peers have much more influence on youth than family, especially parents. Therefore, adolescents do whatever their peers demand from them, which is manifested in the decisions they make and in the way they behave (Allen, Chango, Szwedo, Schad\& Marston, 2012; Gatpandan\&Ambat, 2017; Veerachaisantikul\&Chootarut, 2016). When people that they respect are involved in things like drugs and alcohol, peer pressure can make it very difficult for a child to say no to trying them. A study by Columbia University found that a child is up to six times more likely to have an alcoholic drink if they have friends who drink. However, although this problem is generally thought of as a teenage issue, research has shown that peer pressure may well carry through all age groups, as peer groups continue to exist throughout adult life. Adolescents are particularly vulnerable to peer pressure because they are at a stage of development when they are separating more from their parents' influence, but have not yet established their values or understanding about human relationships or the consequences of their behaviour. They are also typically striving for social acceptance and are more willing to engage in behaviours against their better judgment to be accepted. The adolescents' susceptibility to the influence and also pressure imposed by the peer group depends on many factors, first of all on their mutual closeness and the quality of their friendship (Glaser, Shelton, \&Bree, 2010; Iryani\&Murtiwidayanti, 2017; Manager, 2017; Mai \&Thuy, 2015). Different forms of peer pressure can affect adolescents in various ways. In a negative context, peer pressure can be expressed in ways favoured by the adolescents' characteristics of growth - they are often insecure and they need to feel accepted and belonging to the group. Peer pressure increases in the period of adolescence, and one of the research (Bot, Engels, Knibbe\&Meeus, 2005) propose it may manifest as a very negative impact on the adolescent.

Thus, peer pressure can influence an adolescent to abuse drugs. Various meta-analysis data indicate that an average relationship between peers has a stronger effect on substance use than that of the parents. The adolescent age and type of drug, as a few restricted types of influence, have been taken into account (Allen et al., 2003).

\section{Significance of the Study}

The contribution of the study, besides obtaining valuable new indicators based on scientific research methods, is that they offer guidelines for intervention and treatment in cases of various peer problems and problems with addictive substances abuse.

\section{Research Objectives}

The objective of this study is

i) To determine the correlation between the use of drugs by which they want to experience what the rest of the peer group members already have, and

ii) To determine the characteristics of peer pressure among university students along with their predictive value. 
The point of the study is related to design adequate treatment for students who have difficulties to oppose negative peer pressure and other difficulties occurring in peer relationships, as well as for students who have problems with the abuse of addictive substances in the widest sense.

\section{LITERATURE REVIEW}

Certain authors (McIntosh, MacDonald, \&McKeganey, 2003; Sutthipornphalangkoon, 2016) indicate the need for a differentiation between influence and pressure concepts since, except for the direct coercion, peers influence the adolescents' behaviour in other ways, too. Namely, the choice of like-minded friends and the process of socialisation by which young people internalise the group's attitudes and values are significant for understanding the mechanisms which lead to the manifestation of certain behaviour. However, as numerous research studies, concerning peers, have shown (Lashbrook, 2000; Kiran-Esen, 2003; Brown, 2004; Masuo\&Cheang, 2017), the concept of pressure is tighter than the concept of influence, and it relates to the peer expectation for an adolescent to act in a mode regardless of his/her desires (Lebedina-Manzoni \&Ricijaš, 2013). In a large number of researches, the definition of peer pressure and influence (Almulla, 2018; Coggans\& McKellar, 2009) indicate that the researchers were referring just one isolated factor, in a complex relationship between adolescents as individuals and their peers, ignoring other factors. The role of individuals in their development needs to be re-examined, with particular emphasis on reconsideration of the role of choice and also motivation about substance abuse and interaction with peers. The authors conclude that the assumption that the choice and motivation for substance abuse stems solely from personal or social inappropriateness should be omitted.

A lot of reasons to start using addictive substances are known. Some studies discovered that drug abuse is correlated with serious personal problems. Different emotional states and tensions are reduced by using drugs (Bortner, 1988; Boynton, 1988; Richter, Brown \& Mott, 2010). On the other hand, reasons can be inquisitiveness, protest, a form of behaviour among friends, tryout (George\&Koob, 2010; Khurana, Romer, Betancourt, Brodsky, Giannetta\& Hurt 2015). All aforementioned are characteristics of the student population; however, the literature mostly describes drug abuse through a generic concept (Cato, 1992; McKay, Murphy, McGuire, Rivinus\&Maisto, 1992). The literature points out (Bortner, 1988; Boynton, 1988; Richter, Brown \& Mott, 2010), that drug addicts have a lower sense of their responsibility. Lower sense of responsibility may lead to a lack of self-confidence, their unsatisfactory success, helplessness... The adolescents who are unstable, unsatisfied and unhappy by themselves or the environment they live in, experiment with different substances, and their internal motivation to use the drug again will arise faster. Also, selfcontrol disappears, and habit will develop and turn into an addiction. Just over 1/8 students used different drugs either before or during their university education (Bucher, Vu \&Hojat, 2012; Naeem\&Hameed, 2018; Shams, 2016; Suharti\&Pramono, 2016). One of their hypothesis was confirmed: adolescents who used psychostimulants have significantly higher aggressive-hostility personality factor.

When it comes to the decision on drug consumption, the adolescent's sex should also be considered. Across genders, there are physiological differences and they are influenced by many socio-cultural factors. Different social roles, of men and women, can create different patterns and practices when it comes to using drugs (Zolala, Mahdavian, Haghdoost, \&Karamouzian, 2016).

\section{Hypothesis}

This study proposes the existence of a statistically significant correlation of certain peer pressure characteristics and drug consumption aiming at experiencing what the rest of the peer group members already have. The proposition is based on the assumption, which has been confirmed by former research, that a higher adolescents' autonomy from peers is linked to a higher resilience to the peer influence, which depends on the young people's maturity and increases with age, and vice versa (Allen et al, 2003). Susceptibility to group influence depends on their mutual closeness and the quality of their friendships, as well as on assertive denial (Glaser et al, 2010). As aforementioned, differences in drug-using are evident concerning sex, which is important since the sample observed women are prevailing. Gender differences are evident in reasons of drug use and initiation and also motivation (Zolala et al, 2016).

It is hypothesized that,

H1: There is a significant correlation between certain peer pressure characteristics and drug consumption aiming at experiencing what the rest of the peer group members already have.

\section{METHODOLOGY}

\section{Sample of Examinees}

Examinees were 234 students of the Faculty of Educational Sciences of the JurajDobrila University of Pula, Croatia. Table 1 shows the gender of respondents. 
Table 1: Examinees' sex

\begin{tabular}{lll}
\hline Sex & Aps. & $(\boldsymbol{\%})$ \\
\hline $\mathrm{M}$ & 5 & 2.1 \\
\hline $\mathrm{F}$ & 229 & 97.9 \\
\hline
\end{tabular}

Table 2 shows examinees regarding the study year they attended in the 2018/2019 academic year, indicating that a larger number of examinees (over 86\%) were attending one of the first three years of study, which means that they still were in the upper limits of the adolescent age.

Table 2: Examinees' year of study

\begin{tabular}{ccc}
\hline Year of study & $\begin{array}{c}\text { Number of } \\
\text { students }\end{array}$ & Percentage (\%) \\
\hline 1 & 73 & 31.2 \\
\hline 2 & 78 & 33.3 \\
\hline 3 & 51 & 21.8 \\
\hline 4 & 16 & 6.8 \\
\hline 5 & 16 & 6.8 \\
\hline
\end{tabular}

\section{The Instrument and Data Collection}

The measuring instrument The Peer Pressure Questionnaire was used in the research (Lebedinaet al, 2008). The questionnaire was constructed by the third-year students of Social Pedagogy at the Faculty of Education and Rehabilitation Sciences after the Peer Influence in the Adolescent Period Questionnaire constructed for secondary school pupils by Social Pedagogy Students of the Faculty of Education and Rehabilitation Sciences of the University of Zagreb and adapted by (Lebedina et al., 2007). The author's written consent to use the questionnaire was procured.

The questionnaire consists of 25 items on a five-degree Likert type scale ( $5=$ always, 4=often, 3=sometimes, 2=rarely, $1=$ never). Higher values obtained on the scale represent a higher self-evaluation of susceptibility to peer pressure. The internal consistency of the scale expressed by the Cronbach's alpha coefficient is .89 .

The research was conducted in the 2018/2019 academic year among students of the Faculty of Educational Sciences of the Juraj Dobrila University of Pula. Ethical standards were respected during the questionnaire conduction, while data are used only for scientific purposes. The research was approved by the decision reached by the Committee for the evaluation of the research ethics of the Faculty of Educational Sciences of the Juraj Dobrila University of Pula, Croatia.

\section{Data Analysis}

Besides calculating the basic statistical values, the regression analysis was used in data processing as part of the SPSS program.

\section{RESULTS}

According to arithmetic means of the predictive set of items, it can be noticed that the average item values are different with a special deviation of item It is important to me what my friends think of me (item 13), It is important to me what others think of me (item 3), I choose the place to go out according to the choice and taste of my friends (item 17) and It is important to me to be similar to people I socialize with to feel good (item 1) in the sense that a higher value represents a higher self-evaluation of susceptibility to peer pressure. However, in general, except for the separated items, the susceptibility to peer pressure was self-evaluated to a lower extent, i.e. spanning from never to rarely. Moreover, the offered answer "always" linked to a certain peer pressure characteristic was not chosen in $40 \%$ of the items, while in item 20 (I bet / gamble because my friends also do it) answers "sometimes", "often" and "always" were never chosen.

Table 3: Coefficient of the multiple regression of the predictive set of items and the criterion

\begin{tabular}{ll}
\hline & Value \\
\hline Multiple R & .836 \\
\hline Multiple R2 & .699 \\
\hline Adjusted R2 & .665 \\
\hline $\mathrm{F}$ & 20.234 \\
\hline $\mathrm{P}$ & .000 \\
Std. Err. of Estimate & .306 \\
\hline
\end{tabular}

The regression analysis was done on a predictive set of items that describe certain peer pressure characteristics and the criterion item of drug consumption by which they want to have the experience which the rest of the group already had. The results show that there is a statistically significant correlation between peer pressure characteristics and drug consumption by which they want to have the experience which the rest of the group already had (Table 3). Thus, it is 
possible to predict the use of drugs by which they want to experience what the rest of the peer group members already have. The peer pressure characteristic, as the predictive set of items, explains $84 \%$ of the common variance. The standard regression coefficient (Table 4) is the highest and statistically significant for items:

- When I hang out with people who take drugs I become tempted to try them myself (item12),

- My companions influence my sexual behaviour (item 24) and

- I am afraid I will appear stupid in front of my companions due to my opinion or behaviour (item 7).

The items When I hang out with people who take drugs I become tempted to try them myself (item12), My companions influence my sexual behaviour (item 24) and I am afraid I will appear stupid in front of my companions due to my opinion or behaviour (item 7) mostly contribute to the criterion item of progression, while the other items do not significant.

Table 4: Multiple regression analysis for the criterion

\begin{tabular}{|c|c|c|c|c|c|}
\hline Items & B & $\begin{array}{l}\text { Std. } \\
\text { Error } \\
\text { B }\end{array}$ & Beta & $\mathbf{t}$ & p-level \\
\hline Intercept & .147 & .213 & & .689 & .491 \\
\hline $\begin{array}{l}\text { 1. It is important to me to be similar to people I } \\
\text { socialize with to feel good. }\end{array}$ & 9.764 & .023 & .019 & .422 & 674 \\
\hline $\begin{array}{l}\text { 2. I behave in a way that does not suit me to fit } \\
\text { in with the group. }\end{array}$ & 6.042 & .041 & .071 & 1.485 & .139 \\
\hline 3. It is important to me what others think of me. & -7.908 & .033 & -.012 & -.243 & .808 \\
\hline 4. I compare my looks with others. & -2.648 & .027 & -.047 & -.978 & .329 \\
\hline $\begin{array}{l}\text { 5. My thinking and attitudes are based on the } \\
\text { thinking and attitudes of my companions. }\end{array}$ & -4.281 & .028 & -.069 & -1.536 & .126 \\
\hline $\begin{array}{l}\text { 6. It is more important to me to do what my } \\
\text { peers expect me to than to satisfy my desires. }\end{array}$ & 4.080 & .039 & .049 & 1.042 & .298 \\
\hline $\begin{array}{l}\text { 7. I am afraid I will appear stupid in front of } \\
\text { my companions due to my opinion or } \\
\text { behaviour. }\end{array}$ & -6.317 & .027 & -.109 & -2.337 & $.020 *$ \\
\hline $\begin{array}{l}\text { 8. I will give up my opinion/values or attitudes } \\
\text { if they differ from those of my companions. }\end{array}$ & 2.139 & .040 & .026 & .535 & .593 \\
\hline $\begin{array}{l}\text { 9. I need to be popular among the people I } \\
\text { socialise with. }\end{array}$ & -2.835 & .029 & -.004 & -.096 & .923 \\
\hline $\begin{array}{l}\text { 10. When I am with my friends, I avoid people } \\
\text { who do not belong to my group. }\end{array}$ & 1.849 & .026 & .031 & .724 & .470 \\
\hline $\begin{array}{l}\text { 11. My behaviour is based on the behaviour of } \\
\text { the people in my group. }\end{array}$ & -2.845 & .030 & -.044 & -.958 & .339 \\
\hline $\begin{array}{l}\text { 12. When I hang out with people who take drugs } \\
\text { I become tempted to try them myself. }\end{array}$ & .627 & .038 & .741 & 16.606 & $.000 *$ \\
\hline $\begin{array}{l}\text { 13. It is important to me what my friends think } \\
\text { of me. }\end{array}$ & -2.577 & .024 & -.052 & -1.073 & .285 \\
\hline $\begin{array}{l}\text { 14. When I find myself in a situation where } \\
\text { everyone is drinking alcohol except me, I } \\
\text { have the feeling that I cannot fit in/have } \\
\text { fun/relax. }\end{array}$ & -2.203 & .026 & -.004 & -.084 & .933 \\
\hline $\begin{array}{l}\text { 15. I need to have the same attitudes, values, and } \\
\text { opinions as my friends to feel good among } \\
\text { them. }\end{array}$ & 1.409 & .030 & .023 & .467 & .641 \\
\hline $\begin{array}{l}\text { 16. I need to be praised by my ,gang“" to have a } \\
\text { good opinion of myself. }\end{array}$ & -8.303 & .030 & -.015 & -.281 & .779 \\
\hline $\begin{array}{l}\text { 17. I choose the place to go out according to the } \\
\text { choice and taste of my friends. }\end{array}$ & 2.166 & .021 & .045 & 1.020 & .309 \\
\hline $\begin{array}{l}\text { 18. My friends and I hardly accept people who } \\
\text { are differently dressed or listen to different } \\
\text { kind of music. }\end{array}$ & 2.272 & .025 & .039 & .891 & .374 \\
\hline $\begin{array}{l}\text { 19. I will engage in risky behaviours if my } \\
\text { friends want me to. }\end{array}$ & 7.650 & .049 & .070 & 1.570 & .118 \\
\hline 20. I bet / gamble because my friends also do it. & -8.256 & .166 & -.020 & -.499 & .618 \\
\hline
\end{tabular}




21. I would participate in a student protest, -1.997
$\begin{aligned} & \text { although I do not support their ideas. } \\ & \text { 22. I stay out longer than I would like to because }\end{aligned}$
my friends expect me to.

\section{DISCUSSION}

The research confirms the hypothesis assuming the existence of a statistically significant correlation between certain peer pressure characteristics and drug consumption aiming at experiencing the feeling which the rest of the peer group already has. The aforementioned is confirmed by research when it comes to peer pressure, personality traits and selfesteem (Ginsburg, La Greca\& Silverman, 1998), which means that the pressure imposed on an individual by the peer group is higher if the person has lower self-esteem and vice versa (Kaplan, 2004; Prinstein, 2007). About sexual behaviour, the research conducted by authors Potard, Curtois, \&Rusch (2008), which aimed at determining ,to what degree the predominance of risky sexual behaviour during adolescence is the result of social influence, in particular, that of peers, according to the perception of their attitudes and sexual behaviour, leads to the conclusion that the sexual norms of peers influence young people's attitudes and behaviours. Gender differences in sexual socialization are also important"“.

In our context, considering all of the above, the main role in the phase of adaptation to the university students' life and prevention and intervention in cases of various peer problems, as well as the promotion of health in a wide sense, is given to students' associations and centres and Psychological counselling working at JurajDobrila University in Pula, Croatia“ (Radetić-Paić, Ružić-Baf\&Medaković, 2013) because if a peer problem occurs, the positive influence of the family should be compensated. In that context, learning strategies are important to handle peer pressure effectively, for instance, learn to say no, know yourself, and remember your values, choose the right friends who will support your value.

\section{CONCLUSION}

Different forms of peer pressure can affect adolescents in various ways. In a negative context, peer pressure can be expressed in ways favoured by the adolescents' characteristics of growth - they are often insecure and they need to feel accepted and belonging to the group. Peer pressure increases in the period of adolescence and may manifest as a very negative impact on the adolescent. The current study highlights that peer pressure may affect adolescents adversely and they may begin to abuse addictive substances and become drug addicts. This research has also highlighted avenues that are yet to be explored by future researchers.

\section{LIMITATIONS OF CURRENT RESEARCH}

This research limitation is the relatively small sample of examinees limited to only one university population, as well as the fact that the diverse effects that different drugs have on the user may mean that the reasons for use will closely mirror these differences. Thus stimulants will be used for reasons relating to increased nervous system arousal and drugs with sedatives will be used for reasons relating to an increased nervous system depression“ (Boys, Marsden \&Strang, 2001) and this was not studied in this research, and it could influence results.

\section{RECOMMENDATIONS FOR FUTURE RESEARCH}

Recommendations for further research are, first of all, the number of examinees can be expanded to make the results more representative. Secondly, it is recommended to explore peer influence considering reasons for using different drugs, and thirdly, when it comes to the decision on drug consumption, the adolescent's sex should also be considered.

\section{ACKNOWLEDGEMENT}

Authors would like to pay gratitude to faculty, staff, and students of the Faculty of Educational Sciences, Juraj Dobrila University of Pula, Croatia for cooperation in data collection. Thank you to all.

\section{AUTHORS CONTRIBUTION}

Mirjana Radetić-Paić is a prime author and all the activities concerning data collection, analysis, and interpretation of results along with final write-up are carried by the writer himself.

\section{REFERENCES}

1. Allen, J. P., Chango, J., Szwedo, D., Schad, M., \& Marston, E. (2012). Predictors of susceptibility to peer influence regarding substance use in adolescence. Child Development, 83(1), 337-50. https://doi.org/10.1111/j.1467-8624.2011.01682.x 
2. Allen, M. Donohue, W.A.Griffin, A, Ryan, D., \& Turner, M. M. (2003).Comparing the influence of parents and peers on the choice to use drugs: A meta-analytic summary of the literature. Criminal Justice and Behavior,30(2), 163-186. https://doi.org/10.1177/0093854802251002

3. Almulla, A. (2018). Teachers' and students' perceptions of the academic and socio-emotional benefits of peer tutoring.Journal of Advances in Humanities and Social Sciences, 4(1): 1-12 https://doi.org/10.20474/jahss-4.1.1

4. Bortner, M. A. (1988). Delinquency and Justice. An Age of Crisis. New York, London, Paris, Milano, Tokyo: McGraw-Hill Book Company.

5. Bot, S. M, Engels R. C, Knibbe, R. A, \& Meeus, W. H. (2005). Friend's drinking behaviour and adolescent alcohol consumption: The moderating role of friendship characteristics. Addictive Behaviors, 30(5), 929-947. https://doi.org/10.1016/j.addbeh.2004.09.012

6. Boynton, D. R. (1988). Drug Addiction, LifeStyle Personality Factors and Psychopathology. Georgia: Georgia State University.

7. Boys A., Marsden J., \& Strang J. (2001). Understanding reasons for drug use amongst young people: a functional perspective. Health Education Research, 16(4),457-469. https://doi.org/10.1093/her/16.4.457

8. Brown, B. (2004). Adolescents' relationships with peers. In: R. Lerner, \& L. Steinberg, (Eds.). Handbook of adolescent psychology. 2nd ed. (pp. 363-394). New York: Wiley. https://doi.org/10.1002/9780471726746.ch12

9. Bucher, J. T., Vu, D. M., \& Hojat, M. (2012). Psychostimulant drug abuse and personality factors in medical students. Medical teacher, 35(1), 53-57. https://doi.org/10.3109/0142159X.2012.731099

10. Cato, B. M. (1992). Youth's recreation and drug sensations: is there a relationship? Journal of Drug Education, 22(4), 293-301. https://doi.org/10.2190/WP67-9KRF-VJPG-JRQ5

11. Coggans, N., \& McKellar S. (2009). Drug Use Amongst Peers: peer pressure or peer preference? Drugs: Education Prevention and Policy, 1(1), 15-26. https://doi.org/10.3109/09687639409028532

12. Gatpandan, M. P., \&Ambat, S. C. (2017).Implementing knowledge discovery in enhancing university student services portfolio management in higher education institutions. Journal of Advanced Research in Social Sciences and Humanities, 2(4), 211-220. https://doi.org/10.26500/JARSSH-02-2017-0306

13. George O., \& Koob, G. F. (2010). Individual differences in prefrontal cortex function and the transition from drug use to drug dependence. Neuroscience \& BiobehavioralReviews, 35(2), 232-247. https://doi.org/10.1016/j.neubiorev.2010.05.002

14. Ginsburg, G. S., La Greca, A.M., \& Silverman, W. K. (1998): Social anxiety in children with anxiety disorders: relation with social and emotional functioning. Journal of Abnormal Child Psychology,26(3), 175-185. https://doi.org/10.1023/A:1022668101048

15. Glaser, B., Shelton, H. K., \& Bree, M. (2010). The Moderating Role of Close Friends in the Relationship between Conduct Problems and Adolescent Substance use. Journal of Adolescent Health, 47(1), 35-42. https://doi.org/10.1016/j.jadohealth.2009.12.022

16. Iryani, W. I., \&Murtiwidayanti, S. Y. (2017).Empowering family with social-psychology problem through family care unit (FCU).International Journal of Humanities, Arts and Social Sciences, 3(2), 53-63. https://doi.org/10.20469/ijhss.3.20003-2

17. Kaplan, P. (2004). Adolescence. Boston: Houghton Mifflin Company.

18. Khurana, A., Romer, D., Betancourt, L. M., Brodsky, N. L., Giannetta, J. M., \&Hurt, H. (2015). Experimentation vs. Progression in Adolescent Drug Use: A Test of an Emerging Neurobehavioral Imbalance Model. Development and Psychopathology, 27(3), 901-913. https://doi.org/10.1017/S0954579414000765

19. Kiran-Esen, B. (2003). Examining the adolescents' smoking according to their peer pressure levels and gender. Educational Sciences: Theory \& Practice,3(1), 179-188.

20. Lashbrook, J. T. (2000). Fitting in: Exploring the emotional dimension of adolescent peer pressure. Adolescence, 35(140), 747-757.

21. Lebedina-Manzoni, M., \& Ricijaš, N. (2013). Obilježja mladih s obzirom na podložnost vršnjačkom pritisku [Characteristics of youth regarding susceptibility to peer pressure]. Kriminologija $i$ social integration, [Criminology \& social integration], 21(1), 1-165.

22. Lebedina-Manzoni, M., Lotar, M., \& Ricijaš, N. (2008). Podložnost vršnjačkom pritisku i samopoštovanje kod studenata [Susceptibility to Peer Pressure and Self-Esteem]. Hrvatska revija za rehabilitacijska istraživanja [Croatian review of rehabilitation research], 44(1), 77-92.

23. Mai, L. T., \&Thuy, B. L. (2015). Work-family role conflict: A survey of woman entrepreneurs in Hochiminh city. International Journal of Humanities, Arts and Social Sciences, 1(1), 36-47. https://doi.org/10.20469/IJHSS.20006

24. Manager, D. (2017). The aesthetic dimension of decision making: A case study of a German software company. International Journal of Humanities, Arts and Social Sciences, 3(5), 223-230.

25. Masuo, D., and Cheang, M. (2017). Disconnect between parents' values for saving and actual savings behaviour: Impact on children's education and financial decision-making. Journal of Advances in Humanities and Social Sciences, 3(6): 332-339. https://doi.org/10.20474/jahss-3.6.5

26. McIntosh, J., MacDonald, F., \& McKeganey, N. (2003). The Initial Use of Drugs in a Sample of Pre-teenage Schoolchildren: the role of choice, pressure and influence. Drugs: education, prevention and policy, 10(2), 147158. https://doi.org/10.1080/0968763021000061092 
27. McKay, J. R., Murphy, R. T., McGuire, J., Rivinus, T. R., \& Maisto, S. A. (1992). Incarcerated adolescents' attributions for drug and alcohol use. Addictive Behaviors, 17(3), 227-235. https://doi.org/10.1016/03064603(92)90028-T

28. Naeem, M., \&Hameed, Z. (2018). 'Negative work-family spillover: The relationship between perceived subordinates' negative workplace gossip and supervisor family satisfaction: The role of work-home segmentation preferences'. Journal of Advances in Humanities and Social Sciences 4(2), 104-117. https://doi.org/10.20474/jahss-4.2.5

29. Potard, C., Courtois, R. \& Rusch, E. (2008). The influence of peers on risky sexual behaviour during adolescence. The European Journal of Contraception \& Reproductive Health Care,13(3), 264-270. https://doi.org/10.1080/13625180802273530

30. Prinstein, M. J. (2007). Moderators of peer contagion: A longitudinal examination of depression socialization between adolescents and their best friends. Journal of Clinical Child and Adolescent Psychology,36(2), 159170. https://doi.org/10.1080/15374410701274934

31. Radetić-Paić, M., Ružić-Baf, M., \& Medaković, M. (2013): Experiences and reasons for substances abuse among the students attending the Department of primary education at the University of Pula. Methodical horizons, 8(1),87-94. https://doi.org/10.32728/mo.08.1.2013.06

32. Richter S. S., Brown S.A., \&Mott, M. A. (1991). The impact of social support and self-esteem on adolescent substance abuse treatment outcome. Journal of Substance Abuse,3(4), 371-85. https://doi.org/10.1016/S08993289(10)80019-7

33. Shams, D. (2016). The use of stories in promoting morality among junior high school students.Journal of Advances in Humanities and Social Sciences, 2(3), 168-181. https://doi.org/10.20474/jahss-2.3.5

34. Suharti, L., \&Pramono, A. (2016). Cultural intelligence among Indonesian students: Role of international experiences and their impact on the development of social network and adaptive performance. Journal of Advances in Humanities and Social Sciences, 2(3), 182-194. https://doi.org/10.20474/jahss-2.3.6

35. Sutthipornphalangkoon, C. (2016). A study on the relationship between company characteristics, the demography of engineers and their perception of the AEC and its environment influencing the decision to develop their foreign language skills, in bang poo industrial area, Samutprakarn, Thailand. International Journal of Humanities, Arts and Social Sciences, 2(1), 13-27. https://doi.org/10.20469/ijhss.2.20002-1

36. Veerachaisantikul, A., \&Chootarut, S. (2016). General vocabulary in Thai EFL university students' writing: A corpus-based lexical study. Journal of Advanced Research in Social Sciences and Humanities, 1(1), 52-57. https://doi.org/10.26500/JARSSH-01-2016-0107

37. Zolala, F., Mahdavian, M., Haghdoost, A. A., \&Karamouzian, M. (2016). Pathways to Addiction: A GenderBased Study on Drug Use in a Triangular Clinic and Drop-in Center, Kerman, Iran. International Journal of High-Risk Behaviors and Addiction, 5(2), e22320. https://doi.org/10.5812/ijhrba.22320 